Brit. J. industr. Med., 1965, 22, 279.

\title{
BONE MARROW CHANGES IN SILICOSIS
}

\author{
BY \\ S. E. WARRAKI*, M. Y. GAMMAL, and A. Y. AWNY \\ From the Chest Unit and Clinical Pathology Department, Ain-Shams University Hospital, Cairo, U.A.R.
}

(RECEIVED FOR PUBLICATION MARCH 22, 1965)

\begin{abstract}
Bone marrow specimens were obtained from seven workers who had been exposed to the dust of a calcareous sandstone consisting of $56.3 \%$ free silica. The pattern of changes was in the form of generalized hyperplasia, and in particular there were very high figures for the myeloid series, reticulum cells, and plasma cells. The eosinophils showed a slight but definite increase but the erythrocytes, megakaryocytes, lymphocytes, and monocytes were within the normal range. These changes were considered to be related to silicosis since other diseases causing stimulation of the bone marrow had been adequately excluded.

The findings correlate with the histopathological changes which are reported to occur in the lungs of silicotic patients; they indicate a high degree of stimulation of the reticulo-endothelial system.

If these changes are considered together with the industrial history and clinical and laboratory data, they may provide a clue to the diagnosis of silicosis and help in the differential diagnosis from other diffuse pulmonary lesions.
\end{abstract}

The silica solubility theory dominated the field of silicosis for almost 30 years. Silicic acid, which forms a thin layer covering silica particles, was claimed to exert a toxic effect, leading to collagen formation and ultimately to the production of silicotic nodules. Contradiction of this solubility theory came from various experiments proving that solubility and fibrogenic activity of the dust did not always go hand in hand (King, Mohanty, Harrison, and Nagelschmidt, 1953; Englebrecht, Yoganathan, King, and Nagelschmidt, 1958; Curran and Rowsell, 1958).

Scheel, Smith, Van Riper, and Fleisher (1954) suggested that quartz could denature the proteins and transform them into auto-antigens. Vigliani and Pernis (1958) stated that hyaline precipitation upon the reticular fibrils in the silicotic lesion corresponds to an antigen-antibody reaction. The silicotic hyaline was shown by Pernis and Ghislandi (1956) to differ in its chemical constitution from other hyaline connective tissues; it resembles amyloid, a substance for which an immunological origin is accepted. Further evidence in favour of the autoimmune mechanism in silicosis was provided by Barhad, Vlad, and Dron (1958), Buscarini and

*Present address: 11 Midan El-Falaki, Cairo.
Nicrosini (1959), and Módy, Bors, Barbu, Adorján, Székely, and Szabó (1963), who described an increase in the serum $\beta$ - and $\gamma$-globulin fractions. A general tendency towards a lysozyme increase in the serum was reported by Vogliazzo and Gheis (1961).

Activation of the reticulo-endothelial system (R.E.S.) in silicosis was demonstrated in various organs by Saita and Di Naro (1951) and Vigliani and Pernis (1960). Livers and spleens in animals showed a marked increase in weight together with cellular hyperplasia of the reticulum and plasma cells.

The enlargement of the liver and spleen reported in experimental silicosis is not observed in the human. Bone marrow had not received universal attention in workers exposed to silica dust. The evidence presented in favour of an auto-immunological mechanism operating in silicosis stimulated this study of bone marrow in workers exposed to silica and showing various grades of radiological shadows. The purpose was to investigate these anticipated changes and to clarify their significance in the diagnosis and prognosis of these cases.

\section{Material and Methods}

Seven workers with various grades of silicosis were investigated for possible bone marrow changes. The 
workers dealt with a calcareous sandstone consisting of a mixture of quartz and felspar grains, cemented together in a matrix of silica and calcium carbonate. The chemical composition of the dust particles of respirable size consisted of $56.3 \%$ of free silica. Rocks from various quarries were transported to crusher houses where they were broken into sizes convenient for grinding. Though the atmosphere was visibly very dusty, no methods for the protection of workers were adopted. None of these seven workers was employed in any dusty occupation before joining the plant. Several other cases of silicosis had been reported from the same area.

Clinical examination of all cases revealed no enlargement of the liver, spleen or lymph nodes. No abdominal masses were felt. Sputum analysis was repeatedly negative for acid-fast bacilli by direct smear examinations. Chest radiographs were classified in accordance with the classification of the International Labour Office (I.L.O.), October 1958, as shown in Table 1. Except for case 4 (Fig. 1), they were all cases of simple pneumoconiosis (Figs. 2, 3, and 4).

A single bone marrow puncture was performed in each case. A second puncture would have been more desirable, but this met with difficulty since the study was made on volunteers. Because of this, and for technical reasons, a puncture and not a trephine was adopted. Again, there was no chance of carrying out similar investigations on men of the same age group without silicosis but working in the same plant.

Other diseases possibly causing alteration of bone marrow were adequately excluded. The workers were in-patients in the Chest Section (Ain-Shams University) where they were thoroughly investigated. Laboratory
TABLE 1

RADIOLOGICAL CLASSIFICATION OF THE CASES OF SILICOSIS

\begin{tabular}{|c|c|c|c|c|}
\hline Case & Age & Occupation & $\begin{array}{c}\text { Ex- } \\
\text { posure } \\
(y r .)\end{array}$ & $\mid \begin{array}{c}\text { Radiological } \\
\text { Classifica- } \\
\text { tion }\end{array}$ \\
\hline $\begin{array}{l}1 \text { I.E.K. } \\
2 \text { H.M.G. } \\
3 \text { A.A.E. } \\
4 \text { M.A.H. } \\
5 \text { A.A.E. } \\
6 \text { A.E.A. } \\
7 \text { M.M.F. }\end{array}$ & $\begin{array}{l}54 \\
54 \\
52 \\
60 \\
47 \\
59 \\
45\end{array}$ & $\begin{array}{l}\text { Driller } \\
\text { Unskilled worker (trans- } \\
\text { portation of dust) } \\
\text { On the grinding wheel } \\
\text { (closed chamber) } \\
\text { On the grinding wheel } \\
\text { (closed chamber) } \\
\text { On the grinding wheel } \\
\text { (closed chamber) } \\
\text { Grinding and sieving } \\
\text { Grinding and sieving }\end{array}$ & $\begin{array}{l}20 \\
14 \\
18 \\
32 \\
15 \\
29 \\
20\end{array}$ & $\begin{array}{l}\mathrm{n}_{3-(\mathrm{hi})} \\
\mathrm{p}_{1} \\
\mathrm{~L} \\
\mathrm{p}_{3} \\
\mathrm{~m}_{2-(\mathrm{di}) \cdot(\mathrm{em})} \\
\mathrm{n}_{3} \\
\mathrm{p}_{1}\end{array}$ \\
\hline
\end{tabular}

data showed normal findings including peripheral blood pictures, urine and stool examinations, and serological tests for syphilis, salmonella, and brucellosis. The E.S.R. was normal in all cases except case 4 . The patients were afebrile throughout the time they spent in hospital and they had no skin lesions or itching. A special search was made for parasites in urine, stools, blood, and bone marrow specimens, but all were negative.

\section{Results}

The bone marrow shows a marked to extreme degree of general hyperplasia.

The myeloid series shows a marked hyperplasia of its elements with a normal process of development and maturation. There is a slight but definite

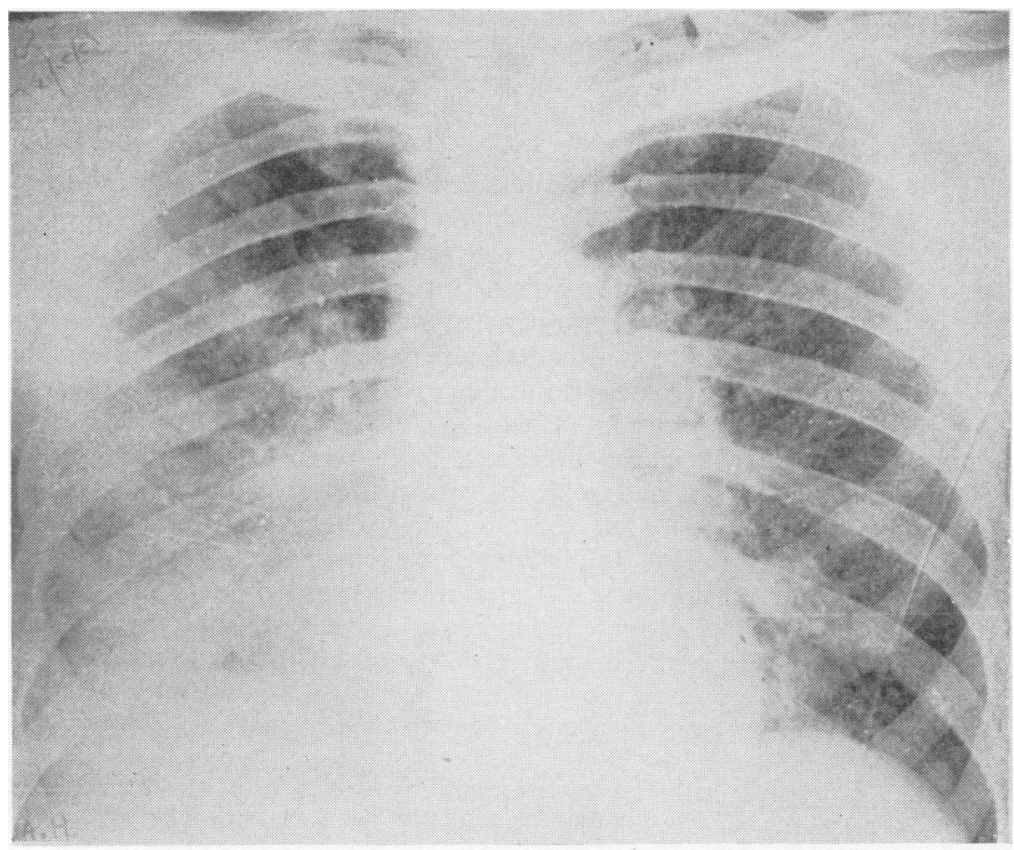

Fig. 1.-Case 4. Punctiform shadows all over both lung fields $\left(p_{3}\right)$. Confluent lesions are seen in the right lower zone ? P.M.F. 


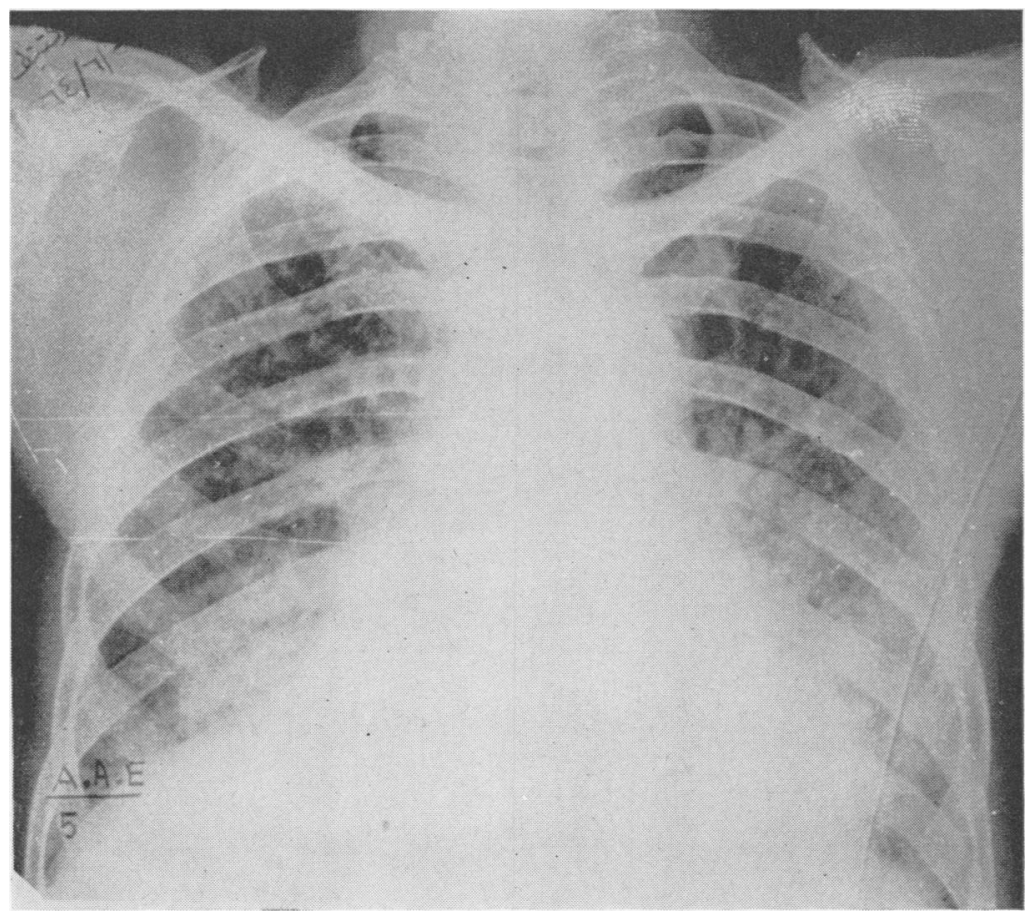

Fig. 2.-Case 5. Shows diffuse miliary shadows, blurring of the
mediastinal borders, and mediastinal borders,
emphysema ( $\left.m_{2-(d i) \cdot(e m)}\right)$.

Fig. 3.-Case 6. Shows nodular shadows all over both lungs $\left(n_{3}\right)$

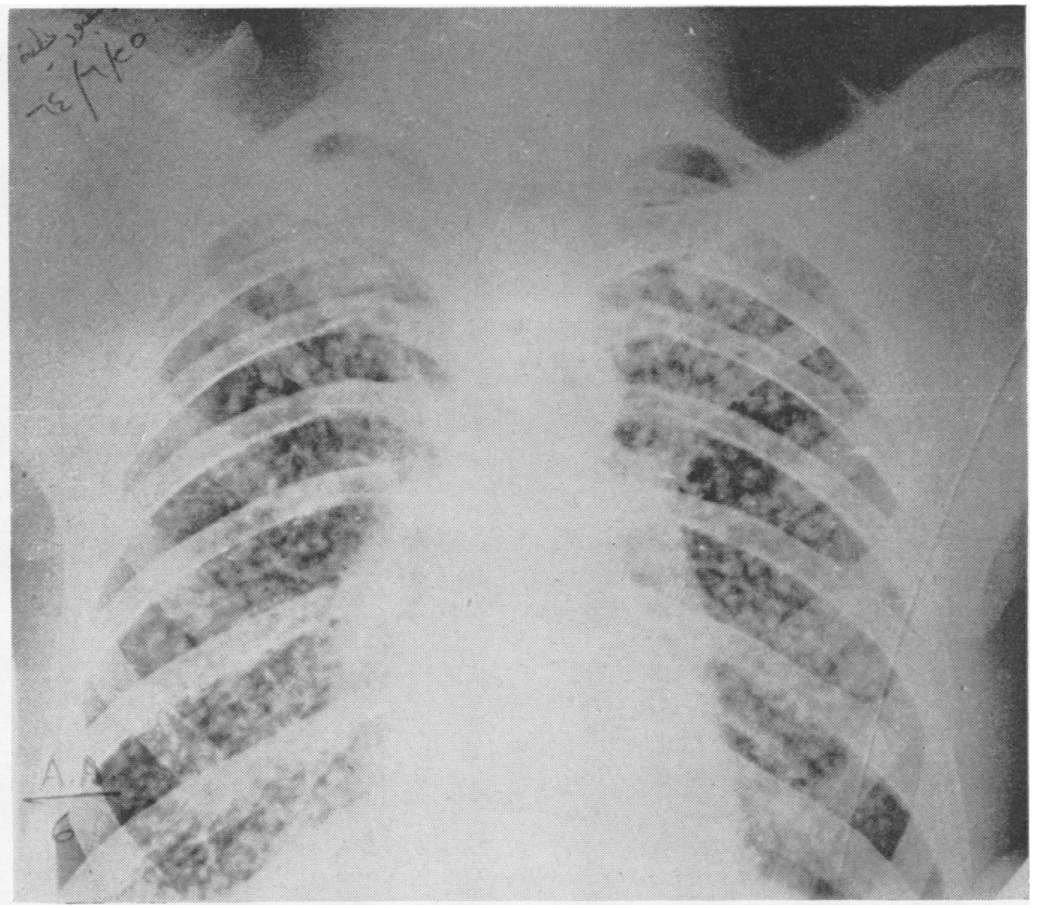




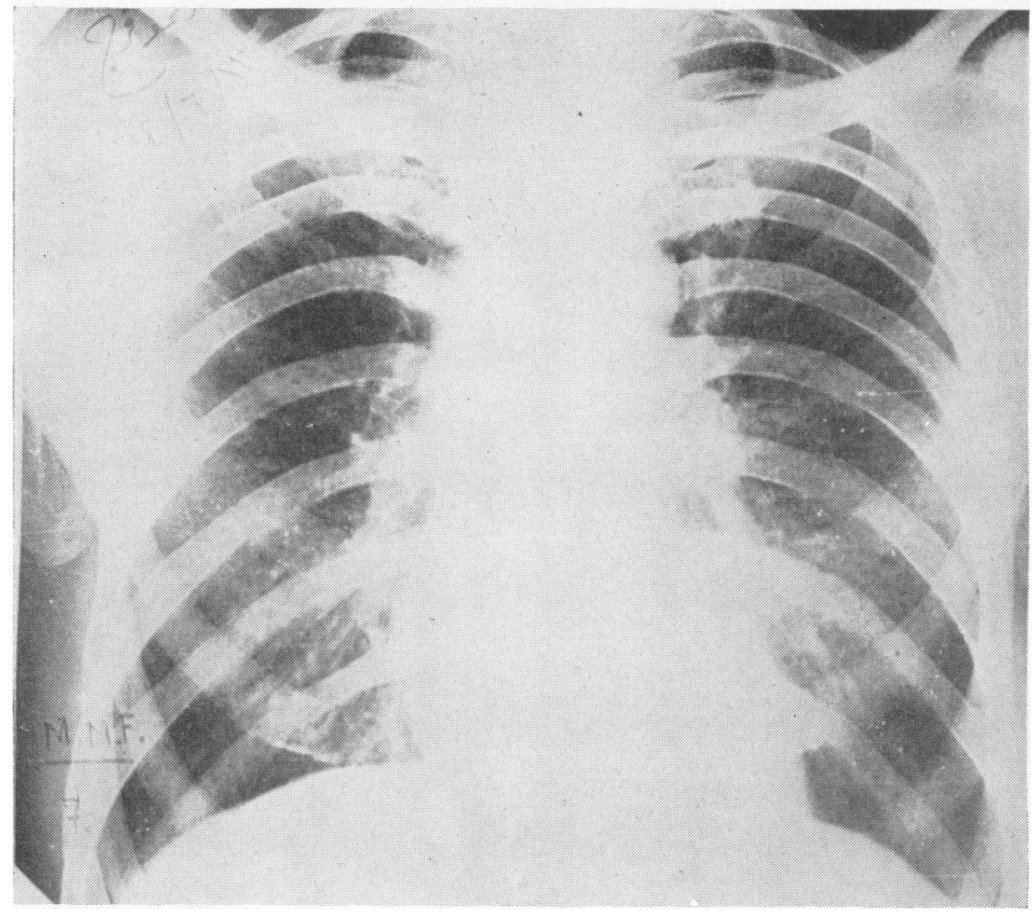

FIG. 4.-Case 7. Shows punctiform shadows in the right mid and lower zones $\left(\mathrm{p}_{\mathbf{1}}\right)$.

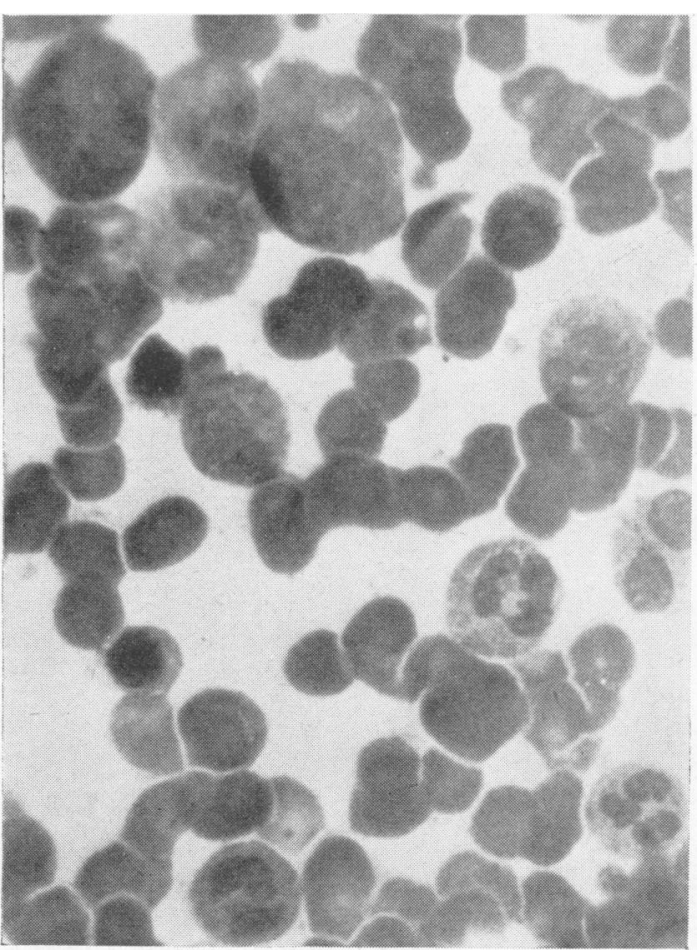

Fig. 5.-Case 7. Bone marrow smear showing general marrow hyperplasia with predominance of myeloid elements. increase in the number of eosinophils (Fig. 5).

The erythroid series shows a normal process of maturation of its elements, which are present in normal numbers.

The megakaryocytes are present in normal numbers and show a normal process of platelet separation (Tables 2,3 , and 4).

The lymphocytes and monocytes are present in fairly normal numbers and show no morphological

TABLE 2

BONE MARROW FINDINGS IN SEVEN CASES OF SILICOSIS

\begin{tabular}{|c|c|c|c|c|}
\hline $\begin{array}{l}\text { Cellular } \\
\text { Elements }\end{array}$ & $\underset{(\%)}{\text { Range }}$ & $\begin{array}{c}\text { Average } \\
(\%)\end{array}$ & $\begin{array}{c}\text { Range* } \\
\text { of Normal } \\
(\%)\end{array}$ & $\begin{array}{c}\text { Average* } \\
\text { Normal } \\
(\%)\end{array}$ \\
\hline $\begin{array}{l}\text { Myeloblasts } \\
\text { Promyelocytes } \\
\text { Myelocytes (neutro- }\end{array}$ & $\begin{array}{l}1 \cdot 5 \cdot 3 \cdot 5 \\
5 \cdot 5-7 \cdot 5\end{array}$ & $\begin{array}{l}2 \cdot 5 \\
6.0\end{array}$ & $\begin{array}{l}0 \cdot 3-5 \cdot 0 \\
1 \cdot 0-8 \cdot 0\end{array}$ & $\begin{array}{l}2 \cdot 0 \\
5 \cdot 0\end{array}$ \\
\hline $\begin{array}{l}\text { philic) } \\
\text { Metamyelocytes } \\
\text { Polynuclear }\end{array}$ & $\begin{array}{l}12 \cdot 5-16 \cdot 0 \\
20 \cdot 5-25 \cdot 5\end{array}$ & $\begin{array}{l}13 \cdot 5 \\
23 \cdot 0\end{array}$ & $\begin{array}{r}5 \cdot 0-19 \cdot 0 \\
13 \cdot 0-32 \cdot 0\end{array}$ & $\begin{array}{l}12 \cdot 0 \\
22 \cdot 0\end{array}$ \\
\hline $\begin{array}{l}\text { neutrophils } \\
\text { Eosinophils (includ- }\end{array}$ & $19 \cdot 5-24 \cdot 0$ & $22 \cdot 0$ & $7 \cdot 0-30 \cdot 0$ & $20 \cdot 0$ \\
\hline $\begin{array}{l}\text { ing myelocytes) } \\
\text { Basophils (including }\end{array}$ & $4 \cdot 5-6 \cdot 0$ & 5.0 & $1 \cdot 0-7 \cdot 0$ & 3.5 \\
\hline $\begin{array}{l}\text { myelocytes) } \\
\text { Lymphocytes } \\
\text { Plasma cells } \\
\text { Monocytes } \\
\text { Reticulum cells } \\
\text { Megakaryocytes } \\
\text { Normoblasts } \\
\text { Pronormoblasts }\end{array}$ & $\begin{array}{l}0 \cdot 5 \\
2 \cdot 5-7 \cdot 0 \\
1 \cdot 5-4 \cdot 0 \\
1 \cdot 0-2 \cdot 5 \\
3 \cdot 0-8 \cdot 5 \\
0 \cdot 5 \\
7 \cdot 5-11 \cdot 0 \\
2 \cdot 0-3 \cdot 5\end{array}$ & $\begin{array}{r}0.5 \\
4.5 \\
2.5 \\
1.5 \\
6.5 \\
0.5 \\
10.0 \\
2.5\end{array}$ & $\begin{array}{c}0-1 \cdot 2 \\
3 \cdot 0-17 \cdot 0 \\
0-2 \cdot 0 \\
0 \cdot 5-5 \cdot 0 \\
0 \cdot 1-2 \cdot 0 \\
0 \cdot 03-3 \cdot 0 \\
7 \cdot 0-32 \cdot 0 \\
1 \cdot 0-8 \cdot 0\end{array}$ & $\begin{array}{r}0 \cdot 5 \\
10 \cdot 0 \\
0 \cdot 4 \\
2 \cdot 0 \\
0 \cdot 2 \\
0 \cdot 4 \\
18 \cdot 0 \\
4 \cdot 0\end{array}$ \\
\hline
\end{tabular}

*After Wintrobe, M., Clinical Haematology, 1961. 
TABLE 3

TOTAL AND DIFFERENTIAL COUNTS OF NUCLEATED CELLULAR ELEMENTS OF BONE MARROWS IN SEVEN CASES OF SILICOSIS

\begin{tabular}{|c|c|c|c|c|c|c|c|c|c|c|c|c|c|c|c|}
\hline Case & $\begin{array}{c}\text { Total } \\
\text { Count of } \\
\text { Nucleated } \\
\text { Elements } \\
\text { (per c.mm.) }\end{array}$ & 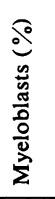 & 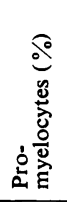 & 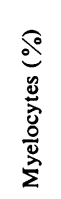 & 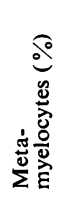 & 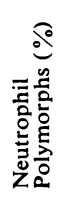 & 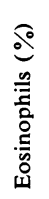 & 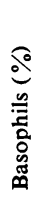 & 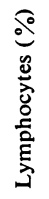 & 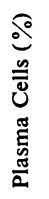 & 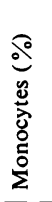 & 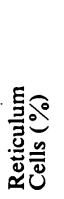 & 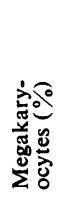 & 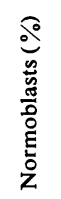 & 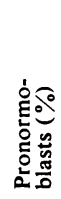 \\
\hline 1 & 306,000 & $3 \cdot 0$ & $7 \cdot 5$ & 12.5 & $24 \cdot 5$ & 22.5 & 5.0 & 0.5 & 2.5 & 2.5 & 1.5 & 8.0 & 0.5 & $7 \cdot 5$ & $2 \cdot 0$ \\
\hline 2 & 288,000 & 2.0 & $6 \cdot 0$ & 13.5 & $21 \cdot 5$ & $22 \cdot 0$ & 5.0 & 0.5 & 7.0 & $2 \cdot 5$ & 2.5 & $4 \cdot 5$ & 0.5 & $11 \cdot 0$ & 3.5 \\
\hline 3 & 416,000 & 1.5 & 6.5 & 15.0 & 23.0 & 21.5 & 4.5 & 0.5 & 3.5 & 1.5 & 1.0 & $6 \cdot 0$ & 0.5 & 11.0 & 3.5 \\
\hline 4 & 318,000 & 2.5 & 5.5 & 12.5 & $25 \cdot 5$ & $24 \cdot 0$ & 4.5 & 0.5 & 5.0 & 1.5 & 1.0 & 3.0 & 0.5 & $11 \cdot 0$ & $3 \cdot 0$ \\
\hline 5 & 324,000 & $2 \cdot 0$ & 5.5 & 14.0 & 20.5 & $19 \cdot 5$ & 5.5 & 0.5 & 5.5 & $4 \cdot 0$ & 1.5 & $6 \cdot 5$ & 0.5 & $10 \cdot 0$ & 2.5 \\
\hline 6 & 278,000 & $2 \cdot 5$ & $6 \cdot 0$ & 16.0 & 20.5 & $21 \cdot 0$ & 6.0 & 0.5 & 5.0 & $2 \cdot 0$ & 1.5 & 8.5 & 0.5 & $7 \cdot 5$ & $2 \cdot 5$ \\
\hline 7 & 365,000 & 3.5 & 6.0 & 12.5 & $23 \cdot 0$ & $22 \cdot 0$ & 5.0 & 0.5 & 2.5 & 3.5 & 2.0 & $7 \cdot 0$ & 0.5 & 10.5 & $2 \cdot 0$ \\
\hline rage & 328,000 & 2.5 & $6 \cdot 0$ & 13.5 & $23 \cdot 0$ & $22 \cdot 0$ & 5.0 & 0.5 & 4.5 & 2.5 & 1.5 & 6.5 & 0.5 & $10 \cdot 0$ & 2.5 \\
\hline
\end{tabular}

TABLE 4

ABSOLUTE COUNTS (cells/c.mm.) OF CELLULAR ELEMENTS OF BONE MARROW IN SEVEN CASES OF SILICOSIS WITH RANGE AND AVERAGE NORMAL VALUES

\begin{tabular}{c|c|c|c|c|c|c|c}
\hline Case No. & Total Count & $\begin{array}{c}\text { Neutrophilic } \\
\text { Elements }\end{array}$ & Eosinophils & Lymphocytes & Plasma Cells & $\begin{array}{c}\text { Monocytes } \\
\text { Reticulum } \\
\text { Cells }\end{array}$ \\
\hline 1 & 306,000 & 214,200 & 15,300 & 7,650 & 7,650 & 4,590 \\
\hline 2 & 288,000 & 187,200 & 14,400 & 20,160 & 7,200 & 7,200 & 12,960 \\
\hline 3 & 416,000 & 280,800 & 18,720 & 14,560 & 6,240 & 4,160 & 24,960 \\
\hline 4 & 318,000 & 222,600 & 14,310 & 15,900 & 4,870 & 3,180 & 9,540 \\
\hline 5 & 324,000 & 199,260 & 17,820 & 17,820 & 12,960 & 4,860 & 21,060 \\
\hline 6 & 278,000 & 183,480 & 16,680 & 13,900 & 5,560 & 4,170 & 23,630 \\
\hline 7 & 365,000 & 244,550 & 18,250 & 9,125 & 12,775 & 7,300 & 25,550 \\
\hline Normal Range & $50,000-100,000$ & $\begin{array}{c}13,150-94,000 \\
(26 \cdot 3 \%-94 \%)\end{array}$ & $\begin{array}{c}500-7,000 \\
(1-7 \%)\end{array}$ & $\begin{array}{c}1,500-17,000 \\
(3-17 \%)\end{array}$ & $\begin{array}{c}0-2,000 \\
(0-2 \%)\end{array}$ & $\begin{array}{c}250-5,000 \\
(0 \cdot 5-5 \cdot 0 \%)\end{array}$ \\
\hline Average Normal & 75,000 & 45,750 & 2,625 & 7,500 & $30-2,000$ \\
$(0.2 \cdot 0 \%)$ \\
\hline
\end{tabular}

anomalies. There is a slight to moderate increase in the number of plasma cells.

The outstanding feature is the marked increase in the number of reticulum cells. Some of the reticulum cells are bi-nucleated or multi-nucleated, morphologically similar to giant cells.

The total counts of the nucleated cellular elements of the marrows examined varied between 278,000 and $416,000 / \mathrm{c} . \mathrm{mm}$. Normal marrow counts usually vary between 50,000 and $100,000 /$ c.mm.

The apparent decrease in the percentage of lymphocytes, monocytes, and erythroid elements brings their absolute values within the normal range, if allowance is made for the approximate three-fold increase in the total count of the nucleated cellular elements. On the other hand, the absolute increase in the reticulum cells would amount to about 100 times their normal numbers. The absolute increase in the plasma cells calculated on this basis would amount to about 20 times.

The myeloid series shows an average increase in the percentage of its elements to $72.5 \%$ of the total nucleated cells of the marrow as compared with the average normal of $65 \%$. This, together with the increase in the total number of the nucleated elements, emphasizes the marked hyperplasia of the myeloid series with a particular further increase in the eosinophils.

These changes are very similar to the changes observed in the bone marrow in certain forms of reticulosis, and particularly in association with malignant lymphoma. However, it was an outstanding feature that in all these cases of silicosis mitotic figures were rare or absent. 


\section{Discussion}

It is pertinent to emphasize that before these bone marrow changes were related to silicosis, thorough clinical examination and investigations were carried out to exclude other diseases that may stimulate the bone marrow, i.e., specific fever, syphilis, leukaemia, Hodgkin's disease, sarcoma, brucellosis, and parasitic infections such as schistosomiasis, malaria, trypanosomiasis, and Kala-azar.

From the results of this work it is clear that the bone marrow picture was definitely abnormal in the cases of silicosis investigated. The changes observed showed a pattern in all seven cases consisting of (1) a generalized hyperplasia with particularly high figures for the myeloid series, reticulum cells, and plasma cells; (2)' a slight but definite increase in eosinophils; and (3) erythrocytes, megakaryocytes, lymphocytes, and monocytes within the normal range.

It is appreciated that if lesions of the bone marrow are focal in distribution, the puncture as well as the trephine biopsies cannot be representative of the overall state of marrow activity. The fact, however, that all the cases showed the same abnormal results may be taken as evidence of the diffuse nature of these abnormalities.

Comparison of these bone marrow changes with the histopathological changes reported in the lungs (and in the liver and spleen in experimental silicosis) reveals a similarity in the intense reaction of activated reticulum and plasma cells.

There was no correlation between the degree of the bone marrow reaction and the extent of the radiological shadows in the lungs. The number of cases reported is, however, too small to allow making such a generalization. None of our cases showed progressive massive fibrosis (P.M.F.) in the chest radiograph; case 4 (Fig. 1) is, however, suspicious. How the changes described in the bone marrow would be altered in degree or pattern by the onset of P.M.F. is beyond the scope of this report.

The findings in the bone marrow in this series do not correlate with those reported by. Velican, Latis, Popa, Popa, and Steinbach (1959) for the peripheral blood. In their series of 33 subjects, they reported a constant increase in eosinophils and monocytes in pre-silicotic and silicotic cases; the haemoglobin and erythrocytes showed an initial increase followed by a fall at the end of two years of underground work. According to their report, these changes occurred three to five years before the disease could be detected radiologically. A pre-radiological humoral phase of silicosis showing these changes, together with an increased blood silica concentration, was assumed to exist. The slight but definite increase in eosinophils in the bone marrows of our cases was the only finding corresponding with Velican's description of the peripheral blood. The pattern described in the bone marrows examined was accompanied by radiological changes in all cases. Whether these bone marrow changes are pre-radiological or not deserves special investigation. Of similar interest would be a study to determine whether such changes would be reversible on removal of the workers from the contaminated atmosphere.

The findings in the marrows of silicotic workers described in this study provide further evidence of stimulation of the reticulo-endothelial system. Their value in supporting an immunological mechanism in silicosis is, however, inconclusive; it would have been ideal in this respect if immuno-conglutinins had been estimated simultaneously in the sera of these cases. When considered together with the clinical and laboratory data, these changes may serve as an additional clue to the diagnosis of silicosis and help in its differentiation from other diffuse pul monary lesions.

\section{REFERENCES}

Barhad, B., Vlad, A., and Dron, F. (1958). Med. d. Lavoro, 49, 419. Buscarini, L., and Nicrosini, F. (1959). Ibid., 50, 368.

Curran, R. C., and Rowsell, E. V. (1958). J. Path. Bact., 76, 561.

Curran, R. C., and Rowsell, E. V. (1958). J. Path. Bact., 76, 561 . G. (1958). Arch. industr. Hlth, 17, 287.

International Labour Office (1959). Meeting of Experts on the International Classification of Radiographs of the Pneumoconioses, Geneva 1958. Occup. Safety Hlth, no. 2, p. 63.

King, E. J., Mohanty, G. P., Harrison, C. V., and Nagelschmidt, G. (1953). Arch. industr. Hyg., 7, 455.

Módy, E., Bors, M. Barbu, Z. Adórján, C., Székely, I., and Szabó, S. (1963). Ftiziologia, 12, 127.

Pernis, B., and Ghislandi, E. (1956). Med. d. Lavoro, 47, 460.

Saita, G., and Di Naro, C. (1951). Ibid., 42, 201.

Scheel, L. D., Smith, B., Van Riper, J., and Fleisher, E. (1954). Arch. industr. Hyg., 9, 29.

Velican, C., Latis, G., Popa, M., Popa, G., and Steinbach, M. (1959). Brit. J. industr. Med., 16, 40.

Vigliani, E. C., and Pernis, B. (1958). Ibid., 15, 8.

and - (1960). Proceedings of the Pneumoconiosis Conference, Johannesburg, 1959, ed. A. J. Orenstein, p. 395. Churchill, Lohannes

Vogliazzo, U., and Gheis, F. (1961). Med. d. Lavoro, 52, 262. 